\title{
Influence of Halal Label on Impulsive Buying Towards Indonesian Society
}

\author{
Nurul Aziza ${ }^{1^{*}}$, Khoirul Hidayat ${ }^{1}$, M Adhi Prasnowo ${ }^{1}$ \\ ${ }^{1}$ Department of Industrial Engineering, Universitas Maarif Hasyim Latif, Sidoarjo, Indonesia \\ *nurul_aziza@dosen.umaha.ac.id
}

\begin{abstract}
Indonesia is a country with the largest Moslem population in the world, this is what makes the prospect of halal products grow and develop in Indonesia. Because for a Muslim is recommended by Islam to consume halal food and beverage. Tinefore it is necessary to research the influence of halal label on impulsive uying towards Indonesian society. Research aims to investigate the effect of halal labe on i npulsive buying towards Indonesian society. Collecting data use nor probability sampling method. The method used in this research is multiple linear meth ds and SWOT analysis. The results of research indicating that the halal label has an in ue on impulsive buying of $52 \%$ and has an effect on a value of 2,8 . Cons er behavior buying a product spontaneously is strongly influenced by a halal label, so hat label incarnation becomes one of the decisions of someone in impulsive buying. SWOT analysis results obtained some strategies that must be done by the food a id beverage industry, among others; to manage halal product certification to Halal 1 oduct Assurance Organizing Agency hereinafter abbreviated (BPJPH), to supervise halar auct from raw material to finished product, to provide training to the work about the importance of halal assurance for the product, to compare the product by giv no tho halal label on product packaging.

Keywords: Halal label; impulsive huying; 1 donesian society
\end{abstract}

\section{Introduction}

Indonesia is a cour ary with the largest Moslem population in the world, this is what makes the prospect of hal r oducts grow and develop in Indonesia. Because for a Muslim is recommended by Islam to consume halal food and beverage. Islam is a religion that guides Muslims in e ery ispect of life. One aspect of guidance that Islam has provided is what can be consumed. M a ms should consume halal food and avoid illegal food. This means that in Islam the conce $t$ t of halal is the absolute key to consumption. Muslims are required to consume only halal food. Muslim consumers eat kosher meat to follow and express their religious teachings [1]. These religious commitments and beliefs affect people's feelings and attitudes toward consumption [2]. Religious obligations and beliefs direct society's attitude and feel to various products, such as food, finance, cosmetics, and pharmaceutical products [3].

Buy that occur when the consumer makes a buy with little or no consideration at all due to a sudden feeling of urgency that raises the desire to have or feel the need of the object is known as impulse buying [4]. Solomon \& Rabolt states that impulse buying is a condition that occurs when the individual experiences a sudden, unresponsive feeling of urgency [5]. It is also supported by Rook \& Fisher's remarks that the tendency to buy spontaneously can generally result in buy when the consumer believes that the action is a natural thing [6]. According to Utami, the phenomenon of impulse buying is not only happening in Indonesia, 